\title{
LIGNIN STUDIES \\ I. Investigations concerning lignin determination
}

\author{
Maija-LiIsa Salo \\ Department of Animal Nutrition and Husbandry, University of Helsinki. \\ Received May 10, 1957
}

Lignin is a cell wall substance with a molecular structure still in many respects hypothetical. Evidently it contains only C, H, and O. Most researchers consider the $\mathrm{N}$ found in lignin preparations an impurity originated from the proteins $(4,12)$. However, some authors (3) are of the opinion that the lignin molecule may contain even N. It is generally agreed that lignin is a macromolecular substance composed of phenylpropane derivatives. By a cautious oxidation both vanillin and syringaldehyde are obtained from lignin (13), and according to some investigators also phydroxybenzaldehyde (14). Alcohols having the same cyclic structure, coniferyl and syringoyl alcohol, are according to FREUDENBERG (9) important intermediary products in the lignin formation in plants. All lignin preparations seem to contain methoxyl groups.

The scanty knowledge concerning the structure of lignin makes the determination difficult. No appropriate components or reactions of lignin are known according to which it would be possible even to prove the presence of lignin in a certain plant product, let alone using them in a quantitative determination. Thus it cannot with certainty be established whether a preparation is pure lignin. It is also impossible exactly to decide upon the eventual solubility of lignin in a certain procedure.

Different methods have been suggested for the determination of lignin. The sulphuric acid methods are the most commonly used and are based on PAYEN's discovery (23) that the carbohydrates in wood are hydrolysed by strong sulphuric acid at room temperature. FleCHSIG (8) was the first to use 72 per cent sulphuric acid in cellulose hydrolysis. This fundamental principle has later been completed with various additional treaments so that the acid methods at present used are rather complicated and laborious.

\section{Review of sulphuric acid methods}

In the earliest methods used for the determination of lignin, extraction with organic solvents was the only pretreatment. The material was, however, usually wood, which makes the smallest demands on the lignin determination. After the 
investigations were extended to herbaceous materials it became evident that a more complicated pretreatment was needed. In the present methods there are commonly three pre-extractions: 1) extraction with organic solvents, 2) extraction with hot water or enzyme digestion, 3) prehydrolysis with dilute acid.

Ethanol-benzene $(1: 2)$ is commonly used for the extraction of lipid substances. The length of extraction time differs in various methods. So e. g. Armitage et al. (1) extract for $2 \frac{1}{2}$ hours, Ellis et al. (7) for 4 hours, Norman and JENkins (17) and Goss and Phillips (10) for 30 hours. Thomas and Armstrong (24) found that the extension of the extraction time from 8 to 16 and further to 30 hours resulted in a considerable increase in the extractives and also in somewhat lower lignin values. Moon and ABou-RAyA (15) mention that a $4-6$ hour extraction removes the so called readily soluble lipid fraction, which is not completely hydrolysed with 72 per cent sulphuric acid. By prolonged extraction, however, further extractives are obtained, but this fraction is soluble in 72 per cent sulphuric acid.

The pretreatment with hot diluted acid is necessary in particular for the removal of readily soluble carbohydrates and proteins. Palohermo (20) drew attention to the fact that fructose and sucrose, when treated with supersaturated hydrochloric acid, gave an insoluble residue up to 25 per cent which, in lignin determination, would appear as lignin. Hilpert and Littman (11) and Norman and Jenkins (17) have pointed out that in addition to those substances also pentosans may cause a serious error, if not removed on prehydrolysis.

Some wood chemists $(5,2)$ deny the use of prehydrolysis because the boiling with dilute acids removes from hardwoods substances having methoxyl contents very similar to those of lignin. According to Moon and ABou-Raya (15) prehydrolysis removes lignin also from herbaceous plants. BRAUns (4), however, considers it doubtful whether a treatment with diluted acid will remove any true lignin.

There are small differences in various methods concerning the length of prehydrolysis and the concentration of the acid. So e. g. Norman and JEnkins (17) and Ellis et al. (7) reflux for 1 hour with 5 per cent sulphuric acid, Goss and PHILLIPS (10) for 1 hour with 1 per cent hydrochloric acid and ARMiTAGE et al. (1) for 1 hour with 5 per cent hydrochloric acid. Which concentration and length of time would lead to most accurate results is as yet not settled.

Prehydrolysis removes also the main part of proteins. However, lignin preparations, separated from materials with high protein contents, always contain nitrogen. This fact was first recognized by Paloheimo (19). He assumed that the nitrogen in the lignin was present as protein and suggested that all lignin values obtained from nitrogen-containing materials should be corrected by subtracting an amount equal to the nitrogen content of the lignin multiplied by 6.25. A similar correction is applied by some other investigators $(25,10)$. The removal of protein has been accomplished also with enzymic digestion. One of the most frequently used enzymes is pepsin $(7,15)$. Trypsin is also used $(1)$, and in yet another method three proteolytic enzymes successively (6). The enzymic digestion removes from plant materials more nitrogen than the acid pretreatment, nevertheless the lignin preparations isolated by methods having an enzymic pretreatment are far from nitrogenfree. 
The hydrolysis of the cellulose is accomplished usually by a treatment with 72 per cent sulphuric acid for 2 hours at $20^{\circ} \mathrm{C}$ with occasional stirring. The mixture is then diluted with water, generally to a concentration of 3 per cent, and the diluted acid solution refluxed for $2-4$ hours $(17,6)$. The hydrolyzed residue is filtered on an asbestos-matted Gooch crucible, washed free of acid with hot water, and dried. The lignin is determined by the loss of weight on ignition.

\section{Experiments and results}

The lignin determination method used by the writer is in the main based on the principles described above. Special attention is called to the fact that the lignin determined by the method should correspond with the indigestible lignin in the matter to be analysed. This fact is important because in our department lignin is used as a tracer in digestibility determinations as well as in investigations concerning the time of the retention of food residues in the alimentary tract $(21,16)$.

The first modification of the method (method A) is carried out as follows:

The material is dried in vacuo at $65^{\circ} \mathrm{C}$ and ground to pass an $1 \mathrm{~mm}$. screen. 2 samples of $2 \mathrm{~g}$. weight are refluxed with $100 \mathrm{ml}$. distilled water for $1 / 2$ hour, filtered into a filter paper and washed with hot water. The residue is transferred into an Erlenmeyer flask with $100 \mathrm{ml} .2 \mathrm{~N}$ hydrochloric acid, refluxed for one hour and filtered into a filter paper, washed with hot water and three times with 94 per cent ethanol. The slightly dried precipitate, together with the filter paper, is introduced into a Soxhlet apparatus and extracted for 8 hours with ethanol-benzene. The dried residue is transferred into a $100 \mathrm{ml}$. beaker, moistened with $5 \mathrm{ml}$. water and mixed with $45 \mathrm{ml} .77$ per cent sulphuric acid. The concentration of the final solution is 72 per cent. Water and acid are kept in a refrigerator to avoid the temperature exceeding $20^{\circ} \mathrm{C}$ by the adding of acid. The beaker is kept for 3 hours in an $18-20^{\circ} \mathrm{C}$ water bath with occasional stirring. After this the contents of the beaker are transferred to a $600 \mathrm{ml}$. beaker and diluted with water up to a volume of $350 \mathrm{ml}$. The solution is heated to boiling point and one of the samples is filtered on an asbestosmatted Gooch crucible and the other on a filter paper. The residues are washed with hot water until free of acid. The ignition loss is determined from the precipitate on the Gooch crucible. This is the crude lignin. The crude protein is determined from the precipitate on the filter paper. The quantity of lignin is obtained by subtracting the protein correction from the crude lignin value.

Method B differs from method A in so far that a pepsin digestion is substituted for refluxing with water. A sample is placed into a $100 \mathrm{ml}$. glass-topped Erlenmeyer flask, which is filled with $0.1 \mathrm{~N}$ hydrochloric acid solution containing 1 per cent pepsin (1: 900). The flasks are then kept for 20 hours at $40^{\circ} \mathrm{C}$ with occasional shaking.

Method A has been proved to be very useful in tracer experiments. By method B some lower and obviously more exact lignin values have been obtained from plant materials containing greater amounts of protein. Further, because the filtration is more rapid after the pepsin digestion than after the refluxing with water, method B saves time. 
Table 1. The effect of the degree of fineness of the material on the results of the analyses. $\mathrm{A}=1 \mathrm{~mm}$. screen, $\mathrm{B}=0.25 \mathrm{~mm}$ screen.

\begin{tabular}{|c|c|c|c|c|c|c|}
\hline & \multicolumn{2}{|c|}{$\begin{array}{c}\text { Membrane } \\
\text { substances }{ }^{1} \text { ) } \\
\% \text { of dry matter }\end{array}$} & \multicolumn{2}{|c|}{$\begin{array}{c}\text { Lignin } \\
\% \text { of dry matter }\end{array}$} & \multicolumn{2}{|c|}{$\begin{array}{l}\text { Crude protein in } \\
\text { crude lignin } \\
\% \text { of crude lignin }\end{array}$} \\
\hline & A & B & A & B & A & B \\
\hline Timothy, early head stage ...... & 43.4 & 41.5 & 4.1 & 3.9 & 19.9 & 20.2 \\
\hline,$\quad$ in bloom $\ldots \ldots \ldots \ldots$ & 61.1 & 57.5 & 8.0 & 7.7 & 12.6 & 12.4 \\
\hline after ripening of seed ... & 62.6 & 61.9 & 9.1 & 9.1 & 5.2 & 4.7 \\
\hline Red clover, in bud $\ldots \ldots \ldots \ldots$ & 30.0 & 28.2 & 4.8 & 4.6 & 32.3 & 32.3 \\
\hline in bloom $\ldots . \ldots \ldots$ & 38.2 & 38.1 & 6.6 & 6.6 & 26.3 & 27.0 \\
\hline after blooming $\ldots$. & 52.4 & 52.4 & 10.5 & 10.0 & 20.8 & 20.3 \\
\hline Birch wood $\ldots \ldots \ldots \ldots \ldots \ldots$ & 91.6 & 91.2 & 12.7 & 12.4 & 1.3 & 1.3 \\
\hline
\end{tabular}

1) Determined by the method of PaLOHEImo (22).

Investigations concerning the significance and the necessity of the different details in the methods have been carried out. As has been stated earlier, the materials to be analysed have been ground in a Wiley mill to pass an $1 \mathrm{~mm}$. screen. In descriptions of lignin determination methods various demands concerning the grade of fineness are prescribed. However, these demands are not experimentally grounded. The writer has made a comparative study of this question. One sample was ground to pass the conventional $1 \mathrm{~mm}$. screen the other to pass a 60 mesh $(0.25 \mathrm{~mm})$ screen. The results presented in Table 1 show that the use of the finer screen resulted in only very slightly lower yields.

The extraction with ethanol-benzene is performed after the prehydrolysis treatments as this has been found to have some practical advantages. In comparative analyses made to study the influence of various locations of the lipid extraction, different materials behaved in different ways. So e. g. the lignin values obtained from young timothy hay and young red clover were lower when the prehydrolysis was made before lipid extraction, but mature hay and clover gave lower results with the pretreatments in the opposite order. The lignin yields obtained from cow faeces were similar with both modifications of the method.

The sufficiency of an 8 hour period for the extraction was also studied by extending the length of the time from 8 to 16 hours. The amounts of extractives obtained by an additional 8 hour extraction were e. g. in full-bloom timothy and red clover only $0.3-0.4$ per cent of the original dry matter. The prolonged extraction diminished, however, to some extent the lignin values, as did the additional treatments in general.

The acid prehydrolysis is made with $2 \mathrm{~N}$ hydrochloric acid. Thus the treatment is more drastic than in the other lignin determination methods. A refluxing with water precedes this treatment since experiments with various materials have shown that boiling with water for $1 / 2$ hour diminishes the lignin values by $0-10$ per cent, in a certain sample of young grass as much as 23 per cent. One reason for this is probably the formation of insoluble substances from fructose and fructosans by boiling even 
in diluted hydrochloric acid. The amount of those substances does not, however, correspond to the decrease in the lignin yield by a pretreatment with water. When e. g. fructose is refluxed with $2 \mathrm{~N}$ hydrochloric acid for 1 hour, the formed insoluble residue is about 2 per cent of the fructose used, and after a subsequent extraction with ethanol-benzene, which removes the greater part of the residue, only about 0.5 per cent is left. Some other water-soluble substances may also interfere with the later treatments.

Metod A contains no enzyme digestion, since it was considered unnecessary because of the use of the protein correction. However, in the later investigations it appeared that the treatment with pepsin, besides the reduction of the protein content of the preparate, had yet another effect on the course of the analysis. This became evident in experiments arranged for checking the competence of the factor 6.25 in the protein correction. In these experiments the samples of different materials were treated with pepsin in the manner described above (pretreatment B) and the controls were treated in the same manner, but without the addition of the enzyme (pretreatment A). Table 2 shows the crude lignin and the lignin percentages obtained after the two pretreatments. It appears that the crude lignin values pertaining to pretreatment $\mathrm{A}$ are greater than the corresponding values pertaining to pretreatment B. The nitrogen percentages of these differences were calculated. As can be seen these percentages are appreciably below the figure 16 which corresponds to the factor 6.25. However, it is hardly possible that the $\mathrm{N}$-percentage of the protein fraction in the crude lignin after pretreatment A could be as low as the figures in the last column of Table 2 indicate. Therefore one must conclude that by digesting the proteins the pepsin facilitates the dissolution of some $\mathrm{N}$-free substances which otherwise would become a part of the crude lignin in full or in part. As to the validity of the protein factor 6.25 in the crude lignin correction the experiments could not give any solution.

As previously mentioned, the pretreated sample is moistened with water before the adding of the strong acid. In that way it is possible to soften and disperse

Table 2. The influence of pepsin on the lignin values.

\begin{tabular}{|c|c|c|c|c|c|}
\hline & \multicolumn{2}{|c|}{$\begin{array}{c}\text { Crude lignin } \% \text { of dry } \\
\text { matter }\end{array}$} & \multicolumn{2}{|c|}{ Lignin $\%$ of dry matter } & \multirow{2}{*}{$\begin{array}{c}\mathrm{N}-\% \text { of the } \\
\text { difference } \\
\mathrm{a}-\mathrm{b}\end{array}$} \\
\hline & $\begin{array}{l}\text { Incubation } \\
\text { without } \\
\text { pepsin } \\
\text { a }\end{array}$ & $\begin{array}{l}\text { Incubation } \\
\text { with pepsin } \\
\text { b }\end{array}$ & $\begin{array}{c}\text { Incubation } \\
\text { without } \\
\text { pepsin } \\
\text { c }\end{array}$ & $\begin{array}{c}\text { Incubation } \\
\text { with pepsin } \\
\text { d }\end{array}$ & \\
\hline Blades of rye $\ldots \ldots \ldots$ & 3.2 & 2.4 & 2.1 & 1.9 & 12.8 \\
\hline Red clover, in bud .... & 6.5 & 4.5 & 4.4 & 3.6 & 9.9 \\
\hline Red clover, in bloom .. & 8.4 & 6.7 & 6.5 & 5.9 & 9.8 \\
\hline Wheat bran $\ldots \ldots \ldots$. & 5.9 & 5.3 & 4.9 & 4.7 & 9.0 \\
\hline Cotton seed cakes $\ldots$. & 7.3 & 6.6 & 5.1 & 4.9 & 10.6 \\
\hline Sunflower cakes $\ldots .$. & 7.6 & 5.8 & 5.1 & 4.6 & 12.0 \\
\hline
\end{tabular}




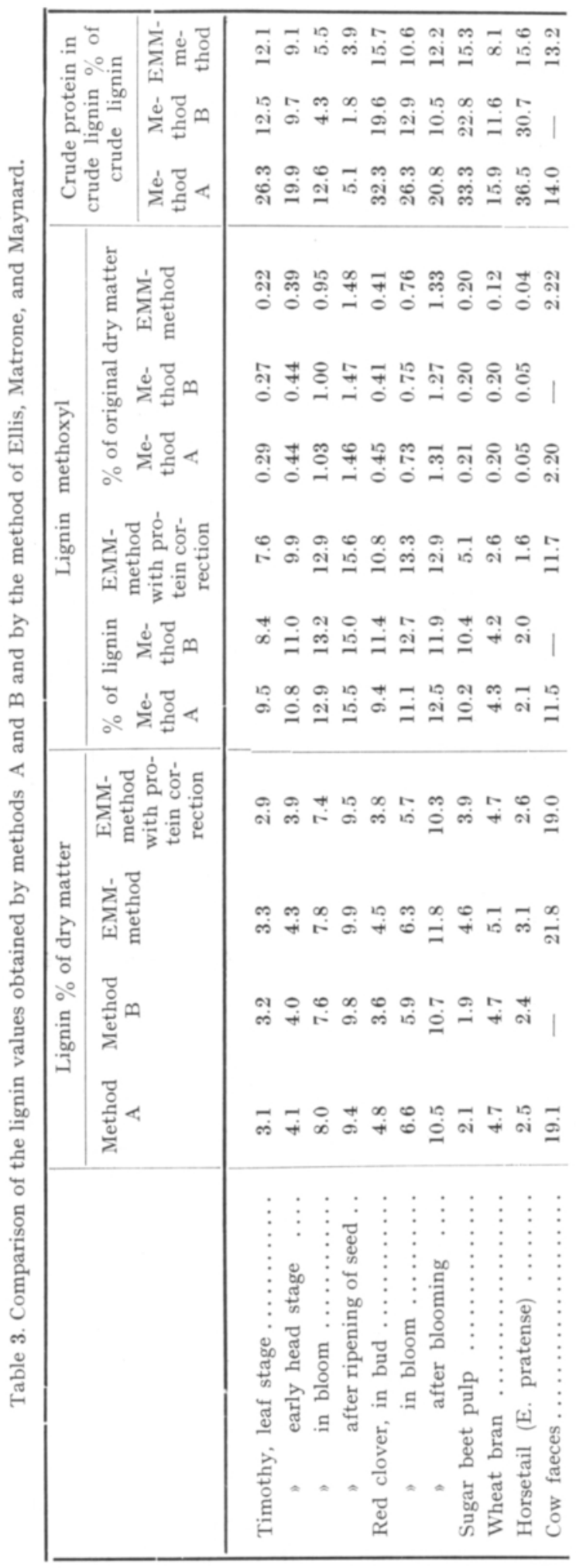


the material, which, after the extraction with ethanol-benzene, in some cases dries into solid pieces. $2-3$ hours are required to complete the hydrolysis at $18-20^{\circ} \mathrm{C}$. The experiments showed that the extension of the hydrolysis time to at least 6 hours had no influence on the lignin yield. Neither did the use of a whisking apparatus instead of the occasional stirring in the beaker have any influence on the result of the analysis. It further appeared that the preceding cooling of the water and the 77 per cent acid were not necessary.

In this method the mixture obtained by the dilution with water is not refluxed but only heated to boiling point. Evidently the effectiveness of the acid prehydrolysis (2 N hydrochloric acid) used makes a longer boiling unnecessary. Only some materials poor in membrane substances seem to demand prolonged boiling. If the generally recommended prehydrolyses either with 2 per cent $(0.56 \mathrm{~N})$ hydrochloric acid or with 5 per cent $(1.05 \mathrm{~N})$ sulphuric acid are used, and the refluxing of the diluted mixture is omitted, higher lignin values are obtained and the methoxyl content of the lignin is low.

In Table 3 the lignin values obtained by methods $\mathrm{A}$ and $\mathrm{B}$ are compared with those obtained by the method of Ellis, Matrone, and Maynard and with the protein corrected values obtained by the same method. The methoxyl contents of the lignin preparations are also given. The methoxyl determinations have been made by a modification of the ZEISEL method (18).

A glance at Table 3 shows that with some materials method B gives somewhat lower lignin values than method A. It is the result of the influence of pepsin as previously shown. There is no significant difference in materials poor in protein. On the nitrogen content of faeces lignin the use of pepsin had no effect. The Ellis et al. method completed with protein correction gave values of the same kind as those obtained by method B. Sugar beet pulp was the only exception. However, from the methoxyl contents of the lignin preparations obtained from this material the conclusion can be drawn that the lignin values obtained by methods $\mathrm{A}$ and $\mathrm{B}$ are more reliable. Altogether it can be concluded that the lignin values obtained by the three methods in question correspond to each other, a fact, which further indicates that the acid methods are not very conventional, provided that certain fundamental principles are followed.

\section{$S u m m$ ary}

In this investigation a sulphuric acid method for the determination of lignin is presented and the influence of various details critically studied.

The samples ground to pass through a 60 mesh $(0.25 \mathrm{~mm}$.) screen gave $0-5 \%$ smaller results than those ground through an $1 \mathrm{~mm}$. screen.

Locating the extraction with ethanol-benzene before or after the prehydrolysis had no significant influence on the lignin values.

The refluxing with water before the acid prehydrolysis lowered the lignin values (N-free) to some extent. The pepsin pretreatment lowered them still further. The nitrogen content of the part of crude lignin which was digested by pepsin was 
$9-13 \%$. On the nitrogen content of crude lignin obtained from faeces the use of pepsin had no influence.

The hydrolysis procedure with 72 per cent sulphuric acid did not appear to be conventional as to the extension of the hydrolysis above the time needed, the effeciency of the stirring of the mixture or the stability of the temperature.

The refluxing of the dilution after 72 per cent acid treatment was not necessary if the acid prehydrolysis was sufficiently effective.

The lignin values obtained by different acid methods correspond to each other provided that certain fundamental principles are followed.

Acknowledgement. The author wishes to express her gratitude to Prof. Lauri Paloheimo for the valuable help given at all stages of this work.

\section{REFERENCES}

(1) Armitage, E. R. \& Ashworth, R. D. \& Ferguson, W. S. 1948. The determination of lignin in plant material of high protein content. J. Soc. Chem. Ind. 67: 241-243.

(2) Bamford, K. F. \& CAmpbell, W. G. 1936. The determination of lignin in the analysis of woods. Biochem. J. 30: $419-428$.

(3) Bondi, A. \& Meyer, H. 1948. Lignins in young plants. Biochem. J. 43: 248-256.

(4) Brauns, F. E. 1952. The chemistry of lignin. 808 p. New York.

(5) Cohen, W. E. \& Harris, E. E. 1937. Pretreatment of wood with hot dilute acid. Effect on lignin values. Ind. Engin. Chem. Anal. Ed. 9: 234-235.

(6) Davis, R. E. \& Mrller, C. O. 1939. Partition of the less easily digested carbohydrate complex of forages. Ibid. 11: $651-652$.

(7) Ellis, G. H. \& Matrone, G. \& Maynard, L. A. 1946. A 72 percent $\mathrm{H}_{2} \mathrm{SO}_{4}$ method for the determination of lignin and its use in animal nutrition studies. J. Anim. Sci. 5: 285-305.

(8) Flechsig, E. 1883. Ueber Darstellung und chemische Natur des Cellulosezuckers. Z. physiol. Chem. 7: $523-540$.

(9) Freudenberg, K. 1952. The formation of lignin in plants. Mitt. österr. Ges. Holzforsch. 4: 40. (Ref. Chem. Abstr. 46: 9172.)

(10) Goss, M. J. \& Phillips, M. 1936. Studies on the quantitative estimation of lignin. I. Factors affecting the determination by the fuming hydrochloric acid method. J. Assoc. Off. Agric. Chem. 19: $341-350$.

(11) Hilpert, R. S. \& Littmann, E. 1934. Uber die Verharzung der Zucker durch Säuren und ihre Beziehung zur Lignin-Bestimmung. Ber. deut. chem. Ges. 67: 1551-1556.

(12) HäGglund, E. 1918. Beiträge zur Kenntnis des Lignins. Ark. kemi, miner. geol. 7, 8: 1-20.

(13) Leger, F. \& Hibbert, H. 1938. Studies on lignin and related compounds. J. Am. Chem. Soc. 60: $565-567$.

(14) Leopold, B. \& Malmström, I.-L. 1952. Studies on lignin. IV. Investigation on the nitrobenzene oxidation products of lignin from different woods by paper partition chromatography. Acta chem. scand. 6: 49-54.

(15) Moon, F. E. \& Abou-RayA, A. K. 1952. The lignin fraction of animal feeding stuffs. III. The determination of total lignin. J. Sci. Food Agric. 3: 595-608.

(16) Mäkelä, A. 1956. Studies on the question of bulk in the nutrition of farm animals with special reference to cattle. Acta agr. fenn. 85: 1-130.

(17) Norman, A. \& Jenkins, S. H. 1934. The determination of lignin. I. Errors introduced by the presence of certain carbohydrates. Biochem. J. 28: 2147-2159. 
(18) Official methods of analysis of the association of official agricultural chemists. 910 p.Wisconsin.

(19) Palohermo, L. 1925. Die Verwendung der Säurehydrolyse zur Ligninbestimmung. Biochem. Z. $165: 463-464$.

$(20) \longrightarrow$ 1926. Lignin determination by acid hydrolysis. 62 p. Helsinki.

(21) —— \& MÄ́kLÄ, A. \& SALo, M.-L. 1955. Some quantitative data on the role of ruminant proventriculi in the digestion and absorption of nitrogen-free organic matter. J. Scient. Agric. Soc. Finl, 27: 70-76.

(22) - \& Palohermo. I. 1949. On the estimation of the total of vegetable membrane substances. Ibid. 21: 1-15.

(23) PAyen, M. 1839. Extrait d'un mémoire sur les ligneux. Compt. rend. 9: 149-153.

(24) Tномаs, B. \& Armstrong, D. G. 1949. A study of some methods at present used for the determination of lignin. J. Agric. Sci. 39: 335-345.

(25) Waksman, S. A. \& Stevens, K. R. 1930. A system of proximate chemical analysis of plant materials. Ind. Engin. Chem. Anal. Ed. 2: 167-173.

\title{
SELOST US :
}

\section{I G N I I N I T U T K I M U K I A}

\section{LIGNIININ MÄÄRITTÄMISTÄ KOSKEVIA TUTKIMUKSIA}

\author{
Maija-Linsa Salo
}

Yliopiston kotieläintieteen laitos, Helsinki

Yliopiston kotieläintieteen laitoksessa on kehitetty ligniinin määrittämistapa, jonka kulku on pääpiirteissään seuraavanlainen. Hienoksi jauhettu näyte keitetään vedessä tai käsitelläån pepsiinillä. Jäännös keitetään $2 \mathrm{~N}$ suolahapossa sekä uutetaan etanoli-bentseenillä. Uutettu jäănnös käsitelläăn 72-prosenttisella rikkihapolla, seos laimennetaan 6 kertaisella vesimäärällä, kuumennetaan kiehuvaksi ja suodatetaan asbestin läpi. Hehkutuskevennyksenä saatuun raakaligniiniin tehdään toisesta näytteestä määritetyn typpimäärän perusteella proteiinikorjaus.

Menetelmän eri vaiheiden merkitystä ja tarpeellisuutta on tutkittu ja kriitillisesti tarkasteltu. 